\title{
SISTEM PENGELOLAAN SAMPAH KECAMATAN LUBUK PAKAM, KABUPATEN DELI SERDANG
}

\author{
WASTE MANAGEMENT SYSTEM \\ LUBUK PAKAM DISTRICT, DELI SERDANG REGENCY
}

\author{
Sheila Nurul Adhana ${ }^{1}$, dan Bimastyaji Surya Ramadhan ${ }^{2}$ \\ ${ }^{1}$ Departemen Teknik Lingkungan, Fakultas Teknik, Universitas Diponegoro JL. Prof, H. Sudarto, SH \\ Tembalang, Semarang, Indonesia, Email : sheilanuruladhana@students.undip.ac.id \\ ${ }^{2}$ Departemen Teknik Lingkungan, Fakultas Teknik, Universitas Diponegoro JL. Prof, H. Sudarto, SH \\ Tembalang, Semarang, Indonesia, Email : bimastyaji@live.undip.ac.id
}

\begin{abstract}
ABSTRAK
Kecamatan Lubuk Pakam adalah Ibukota Kabupaten Deli Serdang yang menjadi pusat beragam aktivitas sehingga menghasilkan sampah jumlah yang tidak sedikit. Timbulan sampah yang dihasilkan adalah 49,04 ton/hari dengan jumlah penduduk pada tahun 2018 menurut data BPS sebanyak 97.996 jiwa. Sampah yang dibiarkan tanpa dikelola akan menimbulkan masalah di lingkungan maupun sosial. Oleh sebab itu, sampah perlu dikelola untuk meminimalisasi dampak buruk tersebut dengan suatu sistem pengelolaan yang terdiri dari beberapa aspek, yaitu teknik operasional, kelembagaan, pembiayaan, peran serta masyarakat, juga hukum dan peraturan. Intansi pemerintah yang berwenang dalam pengelolaan sampah di Kecamatan Lubuk Pakam ialah Dinas Lingkungan Hidup Kabupaten Deli Serdang dan berkoordinasi dengan Seksi Kebersihan Kecamatan Lubuk Pakam. Sistem pengelolaan sampah Kecamatan Lubuk Pakam saat ini meliputi pewadahan, pengumpulan, pemilahan, pengolahan, pemindahan, pengangkutan, dan pemrosesan akhir dengan tingkat pelayanan sebesar 74,5\%. Metode yang digunakan ialah dengan melakukan observasi di lapangan dan analisis deskriptif kondisi eksisting sistem pengelolaan sampah terhadap standar yang berlaku. Hasil penelitian ini menunjukkan bahwa secara umum sistem pengelolaan sampah yang diterapkan sudah terlaksana cukup baik. Namun terdapat hal yang memiliki kekurangan yakni kondisi kendaraan yang terbatas dan peran serta masyarakat dapat dikatakan masih kurang mengenai pemahaman dan tanggungjawab dalam pengelolaan sampah.
\end{abstract}

Kata kunci: Pengelolaan sampah, lima aspek, Kecamatan Lubuk Pakam

\begin{abstract}
Lubuk Pakam Subdistrict is the capital of Deli Serdang Regency which is the center of a variety of activities so as to produce a large amount of garbage. The waste generation that be produced is 49,04 tons / day with a population in 2018 according to BPS data is 97,996 people. Unmanaged waste will cause environmental and social problems. Therefore, waste needs to be managed to minimize these adverse effects with a management system that consists of several aspects, namely operational techniques, institutions, financing, community participation, as well as laws and regulations. The government agency authorized to manage waste in Lubuk Pakam Subdistrict is Dinas Lingkungan Hidup Kabupaten Deli Serdang and coordinates with Seksi Kebersihan Kecamatan Lubuk Pakam. The Lubuk Pakam Subdistrict waste management system currently includes storage, collection, sorting, processing, transfer, transportation and final processing with a service level of 74,5\%. The method used is to make observations in the field and descriptive analysis of the existing conditions of the waste management system against the applicable standards. The results of this study indicate that in general the waste management system applied has been implemented quite well. But there are things that have several shortcomings, that is limited vehicle conditions and community participation that still lacking in understanding and responsibility in waste management.
\end{abstract}

Keyword: Waste management, five aspects, Lubuk Pakam Subdistrict 


\section{Pendahuluan}

Manusia memiliki kegiatan rutin (sehari- hari) yang menghasilkan sisa dalam bentuk padatan yang biasa disebut sebgai sampah. Adapun pengelolaan sampah dilakukan secara sistematis, menyeluruh, dan berkesinambungan dan meiputi pengurangan dan penanganan sampah (UU RI Nomor 18 Tahun 2018). Beberapa dampak dari sampah seperti bau, estetika dan pengaruh terhadap Kesehatan menjadikan pengelolaan sampah sangat penting dilakukan.

Kecamatan Lubuk Pakam merupakan Ibukota Kabupaten Deli Serdang, sehingga menjadi pusat pemerintahan, ekonomi, budaya, serta pendidikan. Meningkatnya pertumbuhan penduduk, industrialisasi, urbanisasi, dan pertumbuhan ekonomi mengakibatkan terjadinya peningkatan yang signifikan terhadap sampah perkotaan (Kaushal dkk., 2012). Pada tahun 2018, Kecamatan Lubuk Pakam memiliki jumlah penduduk sebanyak 97.996 jiwa dengan luas wilayah sebesar 31,19 Km2 (BPS Kab. Deli Serdang, 2019). Menurut data dari DLH Kabupaten Deli Serdang, jumlah timbulan sampah Kecamatan Lubuk Pakam tahun 2018 mencapai 49,04 Ton/hari. Sampah yang berasal dari aktivitas rumah tangga menjadi penyumbang terbesar dalam produksi timbulan sampah Kecamatan Lubuk Pakam sebanyak 19,48 Ton/hari.

Pengelolaan sampah di Kabupaten Deli Serdang terbilang sudah cukup baik, tetapi masih terdapat beberapa kendala yang cukup menghambat pengelolaan persampahan, seperti keterbatasan kondisi kendaraan dan kesadaran masyarakat yang masih rendah mengenai pentingnya pengelolaan sampah. Oleh karena itu, peningkatan sistem pengelolaan sampah yang baik diperlukan untuk menjaga kebersihan lingkungan Kecamatan Lubuk Pakam.

Kerja Praktik ini bertujuan untuk mengetahui kondisi eksisting dan menganalisis sistem pengelolaan sampah di Kecamatan Lubuk Pakam, Kabupaten Deli Serdang. Ditinjau dari lima aspek terdiri dari, aspek teknik operasional, aspek kelembagaan, aspek pembiayaan, aspek regulasi, dan aspek peran serta masyarakat.

\section{Metodologi Penelitian}

Kerja praktik dilakukan selama 24 hari kerja sejak minggu kedua bulan Januari 2020 mulai dari tanggal 6 Januari 2020 sampai dengan 6 Februari 2020 di Dinas Lingkungan Hidup Kabupaten Deli Serdang. Pengumpulan data dilakukan dengan metode observasi, wawancara, dan studi literatur. Sedangkan untuk pengolahan data dilakukan dengan metode analisis deskriptif secara kualitatif dan metode komparatif kondisi eksisting sistem pengelolaan sampah terhadap beberapa standar dan peraturan yang terkait dalam sistem manajemen persampahan.

\section{Hasil dan Pembahasan}

\subsection{Analisis Aspek Teknik Operasional}

\subsubsection{Daerah dan Tingkat Pelayanan}

\section{1) Daerah Pelayanan}

Kabupaten Deli Serdang terdiri dari 22 kecamatan dimana seluruh kecamatan tersebut telah mendapatkan pelayanan persampahan. Luas daerah Kabupaten Deli Serdang adalah $2.497,72 \mathrm{~km} 2$, sehingga perhitungan persentase cakupan pelayanan persampahan Kabupaten Deli Serdang ialah sebagai berikut.

$$
\begin{aligned}
\text { Daerah Pelayanan } & =\frac{\text { luas wilayah terlayani }}{\text { luas wilayah total }} \times 100 \% \\
& =\frac{2497,72 \mathrm{~km} 2}{2497,72 \mathrm{~km} 2} \times 100 \% \\
& =100 \%
\end{aligned}
$$

Dinas Lingkungan Hidup Kabupaten Deli Serdang dalam melaksanakan pelayanan persampahan berkoordinasi dengan masing-masing kecamatan. Persentase pelayanan sampah terbesar ada pada Kecamatan Lubuk Pakam. Hal ini disebabkan karena Kecamatan Lubuk 
Pakam merupakan ibukota kabupaten yang menjadi pusat pemerintahan, ekonomi, pendidikan, dan kebudayaan.

2) Tingkat Pelayanan

Berdasarkan data Neraca Capaian Kerja Pengelolaan Sampah 2018 Lubuk Pakam dari Dinas Lingkungan Hidup Kabupaten Deli Serdang, jumlah timbulan sampah yang dihasilkan Kecamatan Lubuk Pakam ialah sebesar 49,04 ton/hari. Pengelolaan sampah di Kecamatan Lubuk Pakam sudah menerapkan paradigma baru dimana sampah yang dihasilkan tidak seluruhnya dibuang ke TPA, melainkan dikelola dengan pengurangan dan penanganan sampah. Sampah yang dilayani oleh pemerintah adalah sampah yang ditangani dengan penanganan sampah. Jumlah sampah yang berhasil sampah yang berhasil ditangani sebanyak 36,55 ton/hari (terdiri dari terolah menjadi bahan baku, termanfaatkan menjadi sumber energi, dan sampah yang masuk ke TPA). Berikut perhitungan tingkat pelayanan persampahan Kecamatan Lubuk Pakam.

$$
\begin{aligned}
\text { Tingkat Pelayanan } & =\frac{\text { Timbulan penanganan sampah }}{\text { Total timbulan sampah }} \times 100 \% \\
& =\frac{36,55 \text { ton } / \text { hari }}{49,04 \text { ton } / \text { hari }} \times 100 \% \\
& =74,5 \%
\end{aligned}
$$

Berdasarkan perhitungan diatas dapat diketahui bahwa tingkat pelayanan persampahan Kecamatan Lubuk Pakam telah mencapai $74,5 \%$ dari seluruh timbulan yang dihasilkan. Hal ini menunjukkan bahwa terdapat $14,4 \%$ sampah yang dikelola oleh kegiatan masyarakat (pengurangan sampah) dan 11,1\% sampah belum mengalami pengelolaan maupun diangkut ke TPA. Capaian tingkat pelayanan sampah tersebut telah melampaui target yang ditetapkan dalam Pedoman Pengelolaan Persampahan Perkotaan (2003) yaitu $75 \%$ pada tahun 2015.

3) Timbulan Sampah

Dalam menentukan timbulan sampah per kapita di Kecamatan Lubuk Pakam, dibutuhkan data jumlah penduduk Kecamatan Lubuk Pakam dan volume timbulan sampah Kecamatan Lubuk Pakam. Data dari BPS Kabupaten Deli Serdang mencatat bahwa jumlah penduduk Kecamatan Lubuk Pakam sebanyak 97.996 jiwa di tahun 2018. Sedangkan jumlah timbulan sampah yang dihasilkan dari Kecamatan Lubuk Pakam sebesar 49,04 ton/hari pada tahun 2018 atau setara dengan $49.040 \mathrm{~kg} / \mathrm{hari}$.

Timbulan sampah per kapita $=\frac{49,040 \mathrm{~kg} / \mathrm{hari}}{0,5 \mathrm{jiwa}}$

$$
=0,5 \mathrm{~kg} / \mathrm{jiwa} / \mathrm{hari}
$$

Menurut SNI 19-3983-1995, jumlah timbulan sampah untuk kota sedang atau kecil adalah 0,625-0,7 kg/jiwa/hari. Hasil perhitungan timbulan per kapita Kecamatan Lubuk Pakam sebesar $0,5 \mathrm{~kg} / \mathrm{jiwa} /$ hari telah mendekati angka tersebut.

\subsubsection{Pewadahan}

Pewadahan individual yang ada di Kecamatan Lubuk Pakam disediakan secara mandiri oleh masyarakat . Hal ini sesuai dengan SNI 19-2454-2002 yang menyatakan bahwa pewadahan individual disediakan secara pribadi oleh masyarakat atau instansi. Persyaratan wadah sampah menurut SNI 19-2454-2002 yang meliputi bentuk, bahan, sifat, dan pengadaan wadah sampah telah sesuai. Wadah individual harus mudah dipindahkan, ringan, tertutup, tidak mudah rusak, dan kedap air. Umumnya wadah individual yang ada di Kecamatan Lubuk Pakam berbentuk kotak, silinder, ataupun tong yang terbuat dari anyaman bambu atau rotan, juga yang terbuat 
dari plastik ataupun memanfaatkan ban bekas sebagai wadah sampah. Berdasarkan observasi yang dilakukan penulis umumnya tempat sampah tidak memiliki penutup hal ini belum sesuai dengan SNI 19-2454-2002. Pemisahan wadah sampah organik dan anorganik pun masih sangat jarang ditemukan pada wadah individual.

Wadah komunal yang ada di Kecamatan Lubuk Pakam biasanya terletak di daerah komplek perkantoran Pemda Kabupaten Deli Serdang, jalan kota, taman, juga pasar yang disediakan oleh Dinas Lingkungan Hidup Kabupaten Deli Serdang. Hal ini telah sesuai dengan SNI-2454-2002 dimana pewadahan komunal disediakan oleh instansi pengelola persampahan. Akan tetapi terdapat juga pewadahan komunal yang disediakan secara mandiri oleh masyarakat, seperti di kawasan perumahan.

Pewadahan komunal umumnya berupa tong dari plastik atau logam, juga dapat berupa wadah permanen yang terbuat dari pasangan batu bata. Pewadahan sampah yang terpilah antara sampah organik dan anorganik telah dilakukan pada wadah komunal di beberapa tempat, seperti jalan dan taman kota, beberapa kawasan perumahan, dan wadah komunal di komplek perkantoran pemda yang terbuat dari logam. Bahkan untuk wadah yang berada di jalan dan taman kota serta komplek kantor pemda telah dipisahkan menjadi lima jenis sampah seperti yang ditentukan dalam Permen PU No. 3 Tahun 2013. Dalam prakteknya, pemilahan sampah telah dilaksanakan cukup baik di instansi pemerintahan dimana sebagian besar sampah dibuang ke wadah sesuai dengan jenisnya sebab telah dihimbau oleh Dinas Lingkungan Hidup, tetapi dalam prakteknya di masyarakat yakni wadah yang ada di taman dan jalan kota, sebagian besar sampah masih dibuang tidak sesuai wadahnya sehingga menyebabkan sampah organik dan anorganik tercampur.

\subsubsection{Pengumpulan}

Pola pengumpulan sampah dilaksanakan di Kecamatan Lubuk Pakam yaitu pola individual tidak langsung, pola komunal tidak langsung, dan pola penyapuan jalan. Pengumpulan dilakukan oleh petugas dengan menggunakan sepeda motor roda tiga atau betor untuk daerah pemukiman dan pertokoan, sedangkan untuk sampah liar yang berada di sekitar jalan kota dikumpul dengan truk jenis colt diesel jenis dump truck dan mobil pick-up yang melakukan "penyisiran" di sepanjang jalan kota serta arm-roll truck yang mengumpulkan sampah dari TPS/kontainer yang sudah penuh yang kemudian dibawa ke TPS 3R.

Betor menjadi kendaraan utama dalam pengumpulan sampah di pemukiman yang dilakukan sebanyak 3-4 ritasi/hari oleh petugas pengumpul yang mengoperasikan 12 betor. Pengumpulan sampah diselesaikan dalam 1-2 hari dalam satu kawasan pelayanan pengumpulan, tergantung luas daerah pelayanan tiap petugas juga jumlah timbulan yang dikumpulkan. Hal ini telah sesuai dengan jumlah ritasi berdasarkan SNI 19-2454-2002, dimana ritasi pengumpulan sampah dilakukan 1-4 ritasi/hari dan periode pegumpulan satu hari, dua hari, atau maksimal tiga hari sekali tergantung dari kondisi komposisi sampah, kapasitas kerja, desain peralatan dan kualitas pelayananan. Sedangkan pengumpulan sampah yang berupa daun kering dan ranting pohon yang berada di jalan dan taman kota, jalan pinggir kota, maupun pemukiman dilakukan dengan penyapuan

\subsubsection{Pemindahan}

Proses pemindahan sampah dilakukan dari tempat penampungan sementara (kontainer TPS atau TPS 3R) ke kendaraan pengangkut. Untuk sampah yang berada di kontainer TPS seperti TPS Titi PNS, Kantor Bupati, dan Kejaksaan akan dipindahkan dahulu ke TPS 3R Kecamatan Lubuk Pakam untuk dilakukan pemilahan di zona pemilahan. Konsep reduce di TPS 3R Kecamatan Lubuk Pakam dilakukan dengan pemilahan sampah menjadi lima jenis sampah, yaitu sampah organik, plastik, logam/kaca, kardus/kertas, dan B3 rumah tangga atau residu sesuai dengan Permen PU Nomor 3 Tahun 2013. 
Konsep Reuse dilakukan dengan membawa sampah yang bernilai ekonomi akan dibawa ke Bank Sampah Induk "BERSERI" dan juga ada yang dijual ke pengepul agar dapat digunakan kembali. Sementara sampah residu dipindahkan ke kendaran pengangkut secara manual dengan menggunakan alat seperti cakar tiga dan keranjang bambu yang selanjutnya akan diangkut ke TPA Tadukan Raga.

Konsep Recycle yang dilakukan di TPS 3R adalah sampah organik yang diolah menjadi kompos. Pembuatan kompos dilakukan dengan metode open bin dimana terdapat 8 bak kompos yang saat ini telah aktif. Pengomposan ini juga dibantu dengan bantuan mesin pencacah sampah dimana hal ini telah sesuai dengan Permen PU No.3 Tahun 2013. Namun, pupuk kompos yang dihasilkan belum dijual sehingga saat ini hanya diberikan kepada masyarakat, sekolah, perkantoran secara gratis, juga digunakan untuk tanaman yang ada di sepanjang jalan protokol. Menurut Permen PU No. 3 Tahun 2013, lokasi TPS 3R harus mudah di akses. Hal ini telah sesuai karena TPS 3R Kecamatan Lubuk Pakam jalan di sektar TPS 3R cukup lebar sehingga mudah diakses oleh betor maupun truk seperti pada gambar 5.7. Selain itu, seperti yang disebutkan dalam Permen PU No. 3 Tahun 2013, TPS 3R Kecamatan Lubuk Pakam juga telah memilki sarana pengomposan organik, unit penghasil gas bio, gudang penyimpanan sampah daur ulang, dan zona penyangga.

\subsubsection{Pengangkutan}

Kendaraan pengangkut sampah yang beroperasi untuk melayani Kecamatan Lubuk Pakam terdiri dari 2 jenis, yaitu truk colt diesel dan truk fuso. Jenis bak truk colt diesel terbagi atas 2 jenis, yaitu dump truck dan arm roll truck, sedangkan jenis bak pada truk fuso ialah arm roll truck. Terdapat 4 truk colt diesel jenis dump truck, 4 truk colt diesel jenis arm-roll truck, serta 3 truk fuso jenis dump truck. Menurut Permen PU. No.3 Tahun 2013, sampah yang dibawa harus dalam keadaan tertutup selama pengangkutan agar tidak berceceran di jalan. Hal ini telah diterapkan di seluruh kendaraan pengangkut dimana setiap truk minimal memiliki satu penutup berupa terpal dan harus selalu dipasang saat truk akan berangkat menuju TPA Tadukan Raga.

Bak yang dipakai untuk menampung sampah juga tidak boleh bocor, karena dapat mengakibatkan lindi berceceran selama pengangkutan. Pada kondisi eksisting truk yang digunakan, terdapat beberapa truk dengan bak yang berlubang. Walaupun ukuran lubang tidak terlalu besar, tetapi tetap beresiko mengakibatkan sampah dan air lindi ada yang tercecer, terlebih saat hujan. Kondisi truk yang demikian disebabkan karena seluruh armada pengangkutan merupakan armada lama, dimana armada terbaru berasal dari pengadaan tahun 2016. Walau demikian, seluruh armada masih dalam kondisi cukup baik dan masih dapat beroperasi.

Armada pengangkutan beroperasi dari pukul 08.00 hingga pukul 16.00, dimana dimulai dari menyisir sampah dan memindahkan sampah di TPS 3R, lalu mengangkut ke TPA. Perhitungan jumlah ritasi tiap kendaraan ialah sebagai berikut.

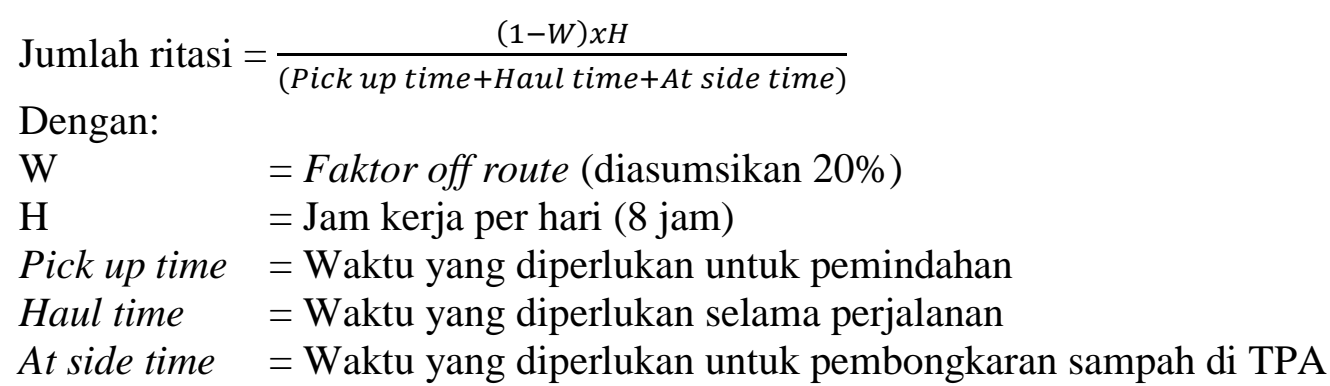

1) Armada colt diesel

a. Bak Jenis Dump

$$
\text { Jumlah ritasi }=\frac{(1-0,2) \times 8}{(1,5 \text { jam }+1,5 \text { jam }+0,5 \text { jam })}
$$




$$
=1,8 \approx 2 \text { ritasi } / \text { hari } / \text { armada }
$$

Rata-rata truk jenis colt diesel dengan bak dump melakukan 2 kali ritasi setiap hari nya, hal ini sesuai pula dengan hasil perhitungan di atas. Akan tetapi, hasil ini belum memenuhi kriteria yang ditetapkan dalam Permen PU No. 3 Tahun 2013, dimana dump truck dapat mencapai efisiensi apabila dapat melakukan ritasi minium sebanyak 3 kali per harinya. Jumlah awak petugas yang dibawa ke TPA ialah sebanyak 1-2 orang, dimana hal ini telah memenuhi kriteria maksimum 3 orang.

b. Bak Jenis Arm-Roll

$$
\begin{aligned}
\text { Jumlah ritasi } & =\frac{(1-0,2) \times 8}{(1 \text { jam+1,5jam }+0,5 j a m)} \\
& =2,1 \approx 2 \text { ritasi } / \text { hari } / \text { armada }
\end{aligned}
$$

Mayoritas truk jenis colt diesel dengan bak arm roll melakukan 2 kali ritasi setiap hari nya, hal ini sesuai dengan hasil perhitungan. Namun, hasil ini belum memenuhi kriteria yang ditetapkan dalam Permen PU No. 3 Tahun 2013, dimana arm roll truck dapat mencapai efisiensi apabila dapat melakukan ritasi minium sebanyak 5 kali per harinya. Sedangkan untuk jumlah awak petugas yang dibawa ke TPA ialah sebanyak lorang, dimana hal ini telah memenuhi kriteria maksimum 1 orang.

\section{2) Armada Fuso dengan Bak Jenis Arm-Roll}

$$
\begin{aligned}
\text { Jumlah ritasi } & =\frac{(1-0,2) x 8}{(3 j a m+1,5 j a m+0,5 j a m)} \\
& =1,28 \approx 1 \text { ritasi } / \text { hari } / \text { armada }
\end{aligned}
$$

Setiap harinya truk jenis fuso dengan bak arm roll melakukan 1 kali ritasi yang sesuai pula dengan hasil perhitungan. Hal ini disebabkan truk Fuso ini khusus mengangkut sampah yang dikumpulkan oleh sepeda motor roda 3 (betor) yang dikumpul sampai pukul 11.00. Namun, hasil ini belum memenuhi kriteria yang ditetapkan dalam Permen PU No. 3 Tahun 2013, dimana arm roll truck dapat mencapai efisiensi apabila dapat melakukan ritasi minium sebanyak 5 kali per harinya. Sedangkan untuk jumlah awak petugas yang dibawa ke TPA ialah sebanyak 1orang, dimana hal ini telah memenuhi kriteria maksimum 1 orang.

\subsubsection{Pemrosesan Akhir}

Tahap akhir dari pengelolaan sampah yang iangkut dari Kecamatan Lubuk Pakam yakni pemrosesan akhir yang dilakukan di TPA Tadukan Raga. Sistem operasi TPA Tadukan Raga bersifat controlled landfill. Hal ini sesuai dengan SNI 19-2454-2002 yang menyebutkan metode pembuangan akhir dapat berupa penimbunan terkendali atau lahan saniter.

Sesuai dengan ketentuan sistem controlled landfll, timbunan sampah di TPA Tadukan Raga ditutup dengan tanah setiap 7 hari sekali. Hal ini telah sesuai dengan Permen PU Nomor 3 Tahun 2013 yang menyebutkan bahwa TPA dengan lahan urug terkendali harus dilakukan penutupan dengan tanah minimum setiap 7 hari sekali. Penutupan tanah rutin ini dilakukan untuk mengendalikan vektor bau dan penyakit, juga untuk mencegah sampah jatuh berserakan dan mencegah bahaya kebakaran. Tanah yang digunakan sebagai penutup ialah jenis tanah merah yang kedap air juga memiliki sifat padat, merapat, dan stabil saat mendapat tekanan.

Mekanisme pengelolaan sampah yang dilakukan di TPA Tadukan Raga meliputi pelaporan yang dilakukan di pos pencatatan, penimbangan dengan jembatan timbang, pembongkaran sampah, pemilahan oleh pemulung dan petugas pengompos, penimbunan sampah, penutupan tanah, pengolahan lindi, dan penyaluran gas metan. 
Zona aktif menjadi tempat pembongkaran dan tempat pemilahan sampah. Sampah yang masih memiliki nilai ekonomis akan dijual ke bank sampah atau pengepul besar, sedangkan sampah yang merupakan limbah B3 disimpan di TPS Limbah B3 . Sampah organik yang dipilah oleh petugas pengompos akan mengolahnya di rumah kompos yang ada di TPA Tadukan Raga dan apabila sudah dikemas akan disimpan di gudang pupuk. UPT Tadukan Raga memutuskan untuk tidak menjual pupuk kompos tersebut, melainkan diberikan secara gratis kepada masyarakat, sekolah-sekolah, maupun perkantoran sekitar yang membutuhkan pupuk untuk dimanfaatkan.

Fasilitas sarana dan prasarana di TPA Tadukan Raga sudah sangat baik sesuai dengan Permen PU Nomor 3 Tahun 2013 dimana telah tersedia jembatan timbang, intalasi pengolahan air lindi, instalasi pemanfaatan gas metan, zona penyangga, rumah kompos dan gudang pupuk, musholla, jalan masuk, jalan operasi, kantor, pos jaga, alat berat berupa excavator, bulldozer, dan loader, garasi/bengkel alat berat, tenpat cuci kendaraan, dan TPS Limbah B3.

\subsection{Analisis Aspek Kelembagaan}

Pengelolaan persampahan di Kecamatan Lubuk Pakam dilaksanakan oleh Dinas Lingkungan Hidup Kabupaten Deli Serdang berkoordinasi dengan Pihak Kecamatan Lubuk Pakam. Untuk di DLH Kabupaten Deli Serdang pengelolaan ini diserahkan kepada Bidang Pengelolaan Sampah dan Limbah B3 (PSLB3) dan pengelolaan sampah skala permukiman dilakukan oleh swadaya masyarakat. Dalam pengelolaan sampah khususnya pengumpulan dan pengangkutan, diserahkan ke masing-masing kecamatan, termasuk Kecamatan Lubuk Pakam melalui Seksi Kebersihan. Sedangkan pengelolaan sampah dengan metode pengurangan dan penanganan sampah, Bidang PLSB3 DLH Kabupaten Deli Serdang membagi tugas ke Seksi Pengurangan Sampah dan Seksi Penanganan Sampah.

Menurut Pedoman Pengelolaan Persampahan Perkotaan yang dikeluarkan oleh Depkimpraswil (2003), pengelola sampah perkotaan harus berbentuk dinas tersendiri. Hal ini masih belum terlaksana di Kabupaten Deli Serdang karena pengelolaan persampahannya masih tergabung dalam Dinas Lingkungan Hidup. Akan lebih baik jika pengelola persampahannya menjadi dinas tersendiri sehingga pengelolaan persampahan menjadi lebih maksimal.

Saat ini DLH Kabupaten Deli Serdang cenderung berperan sebagai regulator. DLH Kabupaten Deli Serdang hanya berperan sebagai operator mengenai pengelolaan sampah di TPA dan beberapa fasilitas pengelolaan sampah milik DLH Kabupaten Deli Serdang. Sedangkan operator persampahan dalam bidang pengumpulan dan pengangkutan sampah diserahkan ke masing-masing kecamatan melalui Seksi Kebersihan. Hal ini menyebabkan datadata pengumpulan dan pengangkutan tidak terintegrasi ke DLH. Peran operator dari dinas dapat dilakukan oleh unit tersendiri melalui UPTD, sehingga dinas berperan sebagai regulator. Hal ini akan dapat memaksimalkan pengelolaan persampahan karena terdapat unit tersendiri yang fokus menanganinya (Dirjen Cipta Karya, 2015).

\subsection{Analisis Aspek Pembiayaan}

Biaya operasional persampahan Kecamatan Lubuk Pakam berdasarkan data dari Pihak Kecamatan Lubuk Pakam meliputi gaji buruh harian lepas (BHL), biaya bahan bakar minyak kendaraan, dan biaya pemeliharaan kendaraan (maintenance) dengan total biaya pada tahun 2019 sebesar Rp 6.235.285.000. Sumber dana untuk biaya operasional tersebut sebagian besar bersumber dari Pagu Anggaran Kecamatan Lubuk Pakam yang diturunkan dari APBD Kabupaten Deli Serdang dan retribusi sampah. Dana Pagu Anggaran Kecamatan Lubuk Pakam yang diturunkan tahun 2019 ialah sekitar Rp 10 Milyar, sedangkan retribusi sampah yang didapat sebesar Rp161.411.000.

Tarif retribusi yang digunakan di Kecamatan Lubuk Pakam berasal dari struktur dan tarif retribusi yang tercantum dalam Perda Kabupaten Deli Serdang Nomor 2 Tahun 2012 tentang 
Retribusi Jasa Umum. Realisasi retribusi tahun 2019 yang terkumpul hanya mencapai 62\% target retribusi sampah yang telah ditetapkan pada tahun 2019 yakni sebesar Rp 262.500.000. Hal ini dikarenakan oleh beberapa hal, yaitu:

1) Rendahnya kesadaran masyarakat untuk membayar retribusi

2) Belum ada sanksi bagi yang tidak membayar retribusi sehingga masyarakat masih mengganggap sepele terhadap retribusi sampah

Perhitungan persentase sumber dana untuk pembiayaan persampahan Kecamatan Lubuk Pakam dari:

a. Restribusi Sampah

$=\frac{\text { Penerimaan Retribusi Kebersihan Kec. Lubuk Pakam }}{\text { Biaya Operasional Sampah Kec. Lubuk Pakam }} \times 100 \%$

$=\frac{161.411 .000}{6.235 .285 .000} \times 100 \%$

$=2,59 \%$

b. Pagu Anggaran Kec. Lbk. Pakam

$=100 \%-2,59 \%$

$=97,41 \%$

Berdasarkan perhitungan di atas, didapatkan bahwa persentase sumber biaya operasional persampahan dari Pagu Anggaran Kecamatan Lubuk Pakam sebesar 97,41\% lebih besar dari persentase sumber biaya dari retribusi sebesar 2,59\%. Kondisi ini belum sesuai dengan Pedoman Pengelolaan Persampahan Perkotaan (2003) dimana seharusnya porsi pembiayaan yang berasal dari APBD (dalam hal ini Pagu Anggaran Kecamatan Lubuk Pakam) lebih kecil dibandingkan retribusi.

\subsection{Analisis Aspek Hukum dan Peraturan}

Pengelolaan persampahan Kecamatan Lubuk Pakam berpedoman pada sistem pengelolaan sampah yang ditetapkan oleh Kabupaten Deli Serdang. Pengelolaan persampahan Kabupaten Deli Serdang mengacu pada Keputusan Bupati Deli Serdang Nomor 271 Tahun 2015 tentang Pedoman Umum Pengelolaan Sampah dan Lingkungan Hidup Kabupaten di Deli Serdang yang mengacu pada UU No. 18 Tahun 2008 tentang Pengelolaan Sampah dan PP RI Nomor 81 Tahun 2012 tentang Pengelolaan Sampah Rumah Tangga dan Sejenis Rumah Tangga. Surat keputusan bupati ini merupakan suatu pedoman yang dapat dijadikan acuan dalam pelaksanaan program program pengelolaan sampah dan lingkungan hidup Deli Serdang BERSERI (Bersih, Rapi, Sejuk, Rindang, dan Indah) secara proporsional, berhasil guna, dan berdaya. Dalam lampiran surat keputusan ini juga terdapat pedoman pengelolaan sampah dan lingkungan hidup khusus di Kecamatan Lubuk Pakam.

Kemudian pada tahun 2018 dikeluarkan Peraturan Bupati Deli Serdang Nomor 24A Tahun 2018 tentang Kebijakan dan Strategi Kabupaten Deli Serdang dalam Pengelolaan Sampah Rumah Tangga dan Sampah Sejenis Rumah Tangga. Peraturan ini memuat arah arah kebijakan pengurangan dan penanganan sampah, serta strategi, program, dan target pengurangan dan penanganan sampah untuk periode tahun 2018-2025. Oleh karena itu, berpedoman dari peraturan tersebut untuk mencapai target pengurangan dan penanganan sampah, maka diterbitkan Surat Edaran Bupati Deli Serdang Nomor 660/2773 Tahun 2019 tentang Pelaksanaan Pengelolaan Sampah 3R (Reduce, Reuse, Recycle) di Lingkungan Perkantoran dan Surat Edaran Bupati Deli Serdang Surat Edaran Bupati Deli Serdang Nomor 660/1928 tentang Kewajiban Menjadi Nasabah Bank Sampah.

Peraturan hukum tentang cara bentuk hukum lembaga dan organisasi pengelola sampah di Kabupaten Deli Serdang mengacu pada Peraturan Bupati Deli Serdang Nomor 2233 Tahun 
2016 tentang Kedudukan, Susunan Organisasi, Tugas dan Fungsi serta Tata Kerja Perangkat Daerah. Dalam peraturan ini dijelaskan tugas pokok dan fungsi serta struktur seluruh Organisasi Perangkat Daerah (OPD) termasuk instansi pengelola sampah yaitu Dinas Lingkungan Hidup. Sedangkan dalam hal penarikan retribusi pelayanan persampahan/kebersihan mengacu pada Peraturan Daerah Kabupaten Deli Serdang Nomor 2 Tahun 2012 tentang Retribusi Jasa Umum. Dengan adanya peraturan-peraturan tersebut maka pengelolaan persampahan Kabupaten Deli Serdang telah memiliki dasar hukum yang jelas yang tentunya menjadi acuan bagi pelaksanaan pengelolaan persampahan di seluruh kecamatan, termasuk Kecamatan Lubuk Pakam. Hal yang perlu ditingkatkan ialah penegakan peraturan-peraturan yang ada agar Perda maupun Keputusan Bupati tersebut dalam berjalan dengan baik.

\subsection{Analisis Aspek Peran Serta Masyarakat}

Peran penting masyarakat dalam pengelolaan persampahan sangat dibutuhkan. Berdasarkan SNI 3242:2008, masyarakat harus melakukan pemilahan sampah organik dan anorganik, melakukan pengolahan sampah dengan konsep 3R, membayar retribusi dan mematuhi aturan pembuangan yang telah ditetapkan. Sayangnya pada kenyataannya, sebagian besar masyarakat belum melakukan pemilahan sampah organik dan anorganik. Padahal hasil pemilahan sampah tersebut dapat di gunakan kembali ataupun dijual ke bank sampah untuk di daur ulang. Hal yang dapat dilakukan untuk meningkatkan kesdaran masyarakat untuk memilah sampah ialah dengan mengadakan sosialisasi. Masyarakat harus diberi edukasi mengenai paradigma baru bahwa sampah yang dihasilkan tidak langsung "diangkut-lalu buang”, akan tetapi dapat dimanfaatkan bahkan dijual. Sosialisasi pun dilakukan sesuai dengan karakter masyarakat agar pesan yang disampaikan dapat diterima dengan baik oleh masyarakat.

Partisipasi masyarakat dalam pengelolaan masyarakat juga dilakukan dengan membayar retribusi kebersihan. Target retribusi kebersihan yang tidak tercapai menunjukkan belum semua masyarakat ikut andil membayar retribusi, padahal hal tersebut bertujuan untuk mendukung pengelolaan sampah di Kecamatan Lubuk Pakam, yang mana apabila pengelolaan sampah yang ada berjalan dengan baik, maka masyarakat pun dapat merasa nyaman dengan keadaan lingkungan sekitar.

Upaya Kabupaten Deli Serdang dalam mewujudkan pengelolaan sampah berbasis masyarakat dilakukan dengan mengaktiflkan bank sampah, khususnya di Kecamatan Lubuk Pakam yang terdapat 4 bank sampah aktif. Salah satu tujuan dari bank sampah untuk mengurangi timbulan sampah, hal ini semakin diperkuat dengan dikeluarkannya Surat Edaran Bupati Deli Serdang Nomor 660/1928 Tahun 2019 tentang Kewajiban Menjadi Nasabah Bank Sampah. Sasaran dari surat edaran ini ialah seluruh Instansi Perangkat Daerah Kab. Deli Serdang, dan seluruh Kantor Desa/Kelurahan, puskesmas, sekolah dan SMP se-Kecamatan Lubuk Pakam, serta RSU Deli Serdang. Dengan adanya surat edaran ini, diharapkan masyarakat dapat ikut menjadi nasabah bank sampah mengikuti pemerintah daerah dan jajarannya. Berdasarkan observasi yang dilakukan penulis, bank sampah induk disana yang bernama Bank Sampah Induk "BERSERI" secara umum sudah memenuhi persyaratan dan standar dalam Permen LH Nomor 13 Tahun 2012 (meliputi persyaratan konstruksi, standar manajemen, dan pelaksanaannya).

\subsection{Analisis Keseluruhan Aspek}

Keseluruhan aspek pengelolaan persampahan Kecamatan Lubuk Pakam dianalisis dan dibandingkan secara langsung antara kondisi eksisting dengan standar acuan peraturan yang ada dengan metode skoring secara keseluruhan aspek. Dengan bobot skor 1, 2, dan 3 untuk 50 parameter yang dibuat penulis, pengelolaan sampah Kecamatan Lubuk Pakam mendapatkan skor sebesar 137 dari skor maksimum 150, atau setara dengan 91,33\%. Sedangkan apabila di skoring setiap masing-masing aspek, maka didapat hasil berikut. 
Tabel 1. Analisis Kesesuaian Masing-Masing Aspek Pengelolaan Persampahan Kecamatan Lubuk Pakam

\begin{tabular}{lccc}
\hline $\begin{array}{c}\text { Aspek Pengelolaan } \\
\text { Sampah }\end{array}$ & $\begin{array}{c}\text { Nilai } \\
\text { Maksimal }\end{array}$ & $\begin{array}{c}\text { Nilai } \\
\text { Hasil } \\
\text { Analisis }\end{array}$ & $\begin{array}{c}\text { Persentase } \\
\text { Ketercapaian } \\
(\%)\end{array}$ \\
\hline Teknik Operasional & 114 & 105 & 92,1 \\
Kelembagaan & 6 & 5 & 83,33 \\
Pembiayaan & 6 & 5 & 83,33 \\
Peran serta Masyarakat & 9 & 4 & 44,4 \\
Hukum dan Peraturan & 15 & 15 & 100 \\
\hline
\end{tabular}

Sumber: Analisis Penulis, 2020

Skoring masing-masing aspek pada Tabel 1 diatas juga menunjukkan hasil yang baik dimana secara umum ketercapaian setiap aspek melebihi dari 50\%. Hal ini menunjukkan bahwa pengelolaan persampahan di Kecamatan Lubuk Pakam, Kabupaten Deli Serdang telah terlaksana dengan cukup baik. Neraca kesetimbangan massa sampah Kecamatan Lubuk Pakam dapat dilihat pada gambar 1 .

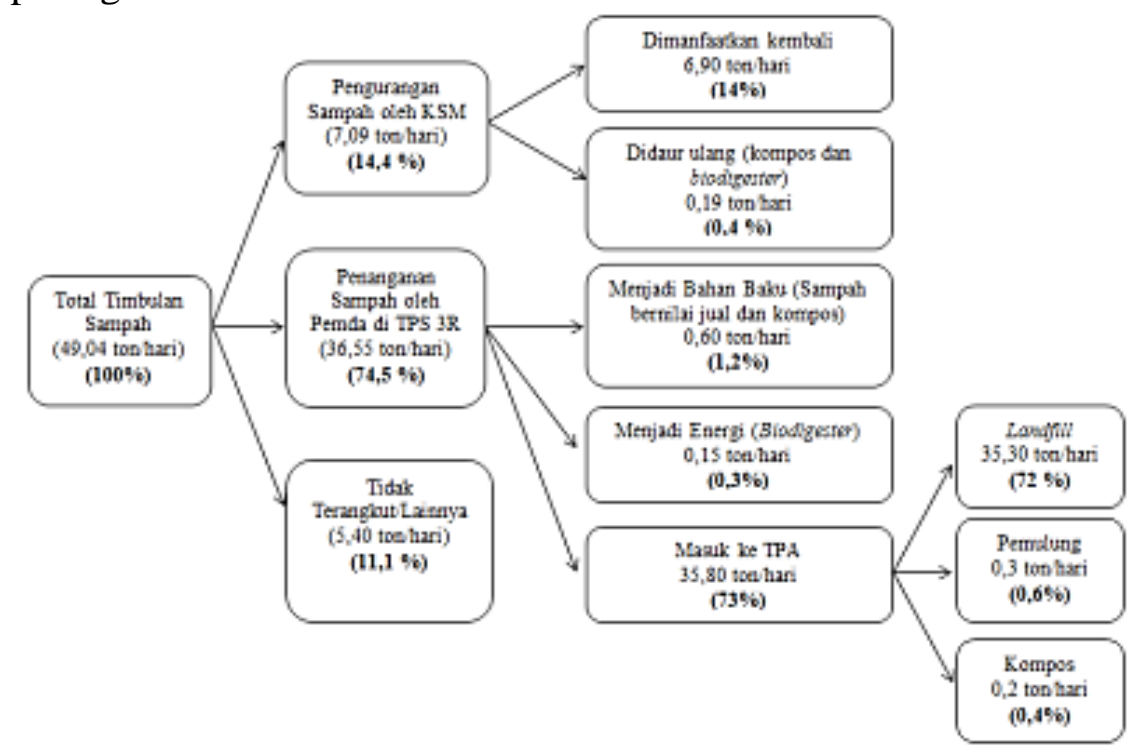

Gambar 1. Neraca Kesetimbangan Massa Sampah Kecamatan Lubuk Pakam Sumber: Analisis Penulis, 2020

\subsection{Peran Pemerintah dalam Pengelolaan Persampahan}

Meningkatnya laju pertumbuhan, pertambahan penduduk, serta aktivitas dan tingkat sosial ekonomi masyarakat, turut mengakibatkan meningkatnya jumlah timbulan sampah. Oleh sebab itu, pengelolaan sampah dengan paradigma lama yaitu "kumpul-angkut-buang" dinilai sudah tidak dapat lagi dilakukan. Oleh karenanya, Pemerintah Kabupaten Deli Serdang berkomitmen untuk mulai melakukan pengelolaan sampah berbasis 3R (Reduce, Reuse, Recycle). Pengelolaan ini dimulai dengan pengelolaan di hulu (dari sumber penghasil sampah), yaitu melakukan pemilahan di sumber penghasil sampah. Langkah ini semakin diperkuat dengan diterbitkannya Surat Edaran tentang Pelaksanaan Pengelolaan Sampah 3R (Reduce, Reuse, Recyle) di Lingkungan Perkantoran yang dikeluarkan oleh Bupati Kabupaten Deli Serdang. Dalam surat ini dihimbau untuk melakukan pembatasan timbulan sampah seperti 
menyajikan makanan secara prasmanan dan menyediakan dispenser untuk air minum ketika rapat, pemanfaatan kembali sampah dengan menyediakan tempat sampah terpilah dan menjadi nasabah bank sampah, serta daur ulang dengan melakukan pengomposan.

Untuk mendukung pemanfaatan kembali sampah melalui bank sampah, Bupati Kabupaten Deli Serdang mengeluarkan Surat Edaran tentang Kewajiban Menjadi Nasabah Bank Sampah. Seluruh instansi perangkat daerah beserta jajaran kebawahnya diwajibkan menjadi nasabah bank sampah. Hal ini dijadikan sebagai contoh bagi masyarakat untuk menggerakkan kesadaran bahwa pengelolaan sampah berbasis masyarakat seperti bank sampah ini, dapat memberikan keuntungan bagi masyarakat itu sendiri, disamping juga dapat menekan biaya operasional penanganan sampah oleh pemerintah.

Selain itu, Pemerintah Kabupaten Deli Serdang juga berinisiatif untuk menjalankan program-program sebagai inovasi untuk meningkatkan kualitas hidup di Kabupaten Deli Serdang, yang diantaranya adalah sebagai berikut.

1. Deli Serdang Berseri

Deli Serdang Berseri merupakan inovasi di bidang informasi teknologi Pemerintah Kabupaten Deli Serdang yang diinisiasi oleh Dinas Lingkungan Hidup Kabupaten Deli Serdang, berupa aplikasi berbasis android yang diunduh di Playstore, yang mempertemukan antara masyarakat yang hendak menjual sampah dengan pihak pengelola Bank Sampah terdekat dari lokasi masyarakat.

2. Jumpa Madu (Jemput Sampah Terima Duit)

Program ini merupakan inovasi layanan pengambilan sampah yang diselenggarakan oleh OPD Dinas Lingkungan Hidup Kabupaten Deli Serdang, dimana masyarakat yang memiliki sampah yang bernilai ekonomi, dapat segera menghubungi admin layanan (Bank Sampah Induk "BERSERI) agar sampah tersebut dijeput untuk dibeli oleh bank sampah.

3. Sumber Bumi (Sampah Bersih, Hubungi Kami)

Sumber Bumi adalah inovasi layanan pengambilan sampah yang diselenggarakan oleh OPD Kecamatan Lubuk Pakam, dimana masyarakat yang melihat timbulan sampah diluar TPS yang diperkenankan dapat menghubungi call center/admin layanan, dan petugas layanan dengan sigap akan datang untuk membersihkan tumpukan sampah tersebut.

4. TPS Basah Komisi (TPS 3R-Bank Sampah-Sampah Rumah Kompos Terintegrasi)

Program ini adalah inovasi untuk operasionalisasi TPS 3R yang terintegrasi dengan Bank Sampah dan Rumah Kompos yang dilakukan oleh Dinas Lingkungan Hidup Kabupaten Deli Serdang sehingga sampah yang dikumpulkan di TPS akan dipilah. Selanjutnya sampah organik dilakukan pengomposan, sedangkan sampah anorganik yang bernilai ekonomis akan dikelola oleh bank sampah, dan residunya diangkut ke TPA.

5. Opung Sari Basah Bang (Operasi Pungut Sampah Setiap Hari, Bank Sampah Sekolah, dan Pembinaan Berjenjang)

Inovasi ini merupakan perwujudan sekolah berbudaya bersih dan peduli lingkungan, dimana peserta didik dibudayakan hidup mampu mengurangi sampah dan memilah sampah serta mampu mengelola Bank Sampah Sekolah. Sekaligus juga inovasi dibidang pembinaan sekolah secara berjenjang. 


\section{Kesimpulan}

1. Secara umum kegiatan operasional pengelolaan persampahan di Kecamatan Lubuk Pakam meliputi kegiatan pewadahan, pengumpulan, pemindahan, dan pengangkutan sampah ke TPA.

2. Berdasarkan hasil pembahasan dengan membandingkan kegiatan operasional persampahan Kecamatan Lubuk Pakam dengan peraturan yang ada, dapat diambil kesimpulan sebagai berikut.

a. Daerah pelayanan persampahan untuk Kabupaten Deli Serdang pada tahun 2018 telah terlayani 22 kecamatan dari 22 kecamatan yang ada dengan Kec. Lubuk Pakam dengan persentase terbesar dengan tingkat pelayanan sebesar $74,5 \%$.

b. Untuk aspek teknik operasional yang diterapkan di Kecamatan Lubuk Pakam sebagian besar telah sesuai dengan ketentuan SNI 19-2454-2002, SNI 3242:2008, Permen PU No. 3 Tahun 2013, dan Pedoman Persampahan Perkotaan (2003).

c. Lembaga yang menjalankan pengelolaan persampahan Kabupaten Deli Serdang adalah Dinas Lingkungan Hidup Kabupaten Deli Serdang melalui Seksi Pengelolaan Sampah dan Limbah B3 (PSLB3) dan berkoordinasi dengan setiap kecamatan termasuk Kecamatan Lubuk Pakam melalui Seksi Kebersihan sebagai pelaksana operasional, namun masih kurang optimal karena belum menjadi dinas tersendiri.

d. Untuk aspek pembiayaan, biaya operasional persampahan Kecamatan Lubuk Pakam mengandalkan APBD sebagai sumber utama. Pembiayaan operasional persampahan Kecamatan Lubuk Pakam bersumber dari Pagu Anggaran Kecamatan Lubuk Pakam sebesar $97,41 \%$ dan dari retribusi sebesar 2,59\%.

e. Untuk aspek hukum dan peraturan, pengelolaan persampahan Kecamatan Lubuk Pakam berpedoman pada peraturan yang dikeluarkan oleh Bupati Deli Serdang, yang terdiri dari peraturan daerah maupun keputusan bupati yang mengatur tentang pengelolaan persampahan, retribusi, serta bentuk lembaga pengelola persampahan kota.

f. Untuk aspek peran serta masyarakat, belum optimal terlaksana karena masih kurangnya kesadaran masyarakat mengenai pengelolaan sampah, seperti masyarakat masih banyak yang belum memilah sampah dari sumber, serta dalam membayar retribusi yang belum maksimal. 


\section{Daftar Pustaka}

Badan Pusat Statistik. (2019). Kecamatan Lubuk Pakam Dalam Angka 2019. Deli Serdang: BPS Kabupaten Deli Serdang.

Undang-Undang Nomor 18 Tahun 2008. tentang Pengelolaan Sampah.

Kaushal, R. J., Varghese, G. K., \& Chabukdhara, M. (2012). Municipal solid waste management in india-current state and future challenges: a review. International Journal of Engineering Science and Technology (IJEST). 4 (04). 1473.

Depkimpraswil. (2003). Pedoman Pengelolaan Persampahan Perkotaan. Jakarta : Direktorat Jenderal Tata Perkotaan dan Tata Pedesaan.

Badan Standarisasi Nasional. (1995). SNI. 19-3964-1995. Metode Pengambilan Dan Pengukuran Contoh Timbulan dan Komposisi Sampah Perkotaan. Jakarta.

Badan Standardisasi Nasional. (2002). SNI 19 - 2454 - 2002 tentang Tata Cara Teknik Operasional Pengelolaan Sampah Perkotaan. Jakarta.

Badan Standardisasi Nasional. (2008). SNI 3242: 2008 tentang Pengelolaan Sampah di Permukiman. Jakarta.

Peraturan Menteri Lingkungan Hidup Nomor 13 Tahun 2012 tentang Pedoman Pelaksanaan Reduce, Reuse, Recycle Melalui Bank Sampah.

Peraturan Menteri Pekerjaan Umum Nomor 3 Tahun 2013 tentang Penyelenggaraan Prasarana dan Sarana Persampahan dalam Penanganan Sampah Rumah Tangga dan Sejenis Sampah Rumah Tangga.

Direktorat Jenderal Cipta Karya. (2015). Panduan Praktis Penataan Kelembagaan Sistem Pengelolaan Persampahan. Jakarta: Kementerian Pekerjaan Umum dan Perumahan Rakyat. 